\title{
Learning to speak each other's languages, again
}

Edition 4, 2020

Philipp Ivanov, Shazleen Lateef

DOI: $10.37839 /$ MAR2652-550X4.2

Melbourne's neighbourhoods, currently deserted and locked-down due to COVID-19, are home to one of the world's most culturally diverse communities. In Australia's second-largest city, you can find most of the world's major cultures, more than 100 nationalities and as many languages.

Melbourne and Sydney are also Australia's gateways to Asia-with an equally diverse community of nations whose prosperity and peace are strongly interlinked with our own.

Economic, health and security crises often create dangerous fault lines within societies and between nations, when the blame for domestic or global problems is attributed to a country, or to an ethnic, religious, or cultural group. We saw this during the White Australia immigration policy in the first half of the 1900s, the 9/11 decade and at the race-related riots in the Sydney suburb of Cronulla in 2005. We see it in our current debate about China's influence on Australia.

The COVID-19 pandemic is a crisis like no other. It has put enormous pressure on our health, economy, and society. It has also exposed vulnerabilities in our multiculturalism and our ability to engage with our region. If uncertainty about the future course of the pandemic and a recession deepen, we may see fractures in our social cohesion. Beyond our borders, a more strategically contested, less affluent and more competitive region will be more difficult for Australia to navigate. Yet it is in this region that we will need to preserve peace and continue to grow our prosperity. 
Now is an opportunity for us to think deeply about both challenges.

Speaking each other's languages and understanding the basics of each other's cultures is a good place to start. It will help us communicate with our neighbours across the street as well as across the ocean.

Too often, the issues of Australia's Asia competency and multiculturalism have existed in parallel policy and intellectual universes. The fact is that they are directly interlinked.

An inclusive and connected community contributes to better social cohesion. It also lifts our capacity to engage with our region and enables a more creative and resilient economy.

\section{Speaking with our community}

Australia's culturally diverse community has grown and thrived over generations because of our immigration and multiculturalism policies, a welcoming society, a dynamic economy, and our democracy and respect for human rights. Migration has also been a major driver of our economic growth, employment and living standards.

Our population reflects Australia's history, and the region around us - with arrivals from China, India, Philippines and Vietnam, catching up with our traditional sources of migration from the United Kingdom and New Zealand.

Successive Australian governments have been remarkably consistent and nonpartisan in their commitment to preserving and protecting this diverse social fabric against ugly manifestations of racism, xenophobia and intolerance.

Australia's multicultural community is as resilient as it is diverse. But the pandemic has exposed invisible but nevertheless real boundaries between these communities and the rest of Australia. These boundaries are economic, social and linguistic. 
Some are structural and will take time to fix. But many are within our reach. We have policy tools, institutions and talent to use this crisis to bridge these divisions.

The first wave of the pandemic in Victoria was centred around affluent suburbs and driven by globally mobile professionals who brought the virus from abroad. The early epicentres of the second and much larger wave were in the outer neighbourhoods of Melbourne, a home to many multicultural communities.

The major factor behind this is insecure work-as Victorian Premier Daniel Andrews acknowledged early in the second wave of the pandemic-forcing our young and new Australians to work multiple jobs across different sites, with no sick leave and in fear of losing their incomes. One of the other factors-by no means considered critical and yet to be comprehensively examined-is a breakdown in communications between government and community due to the quality and effectiveness of the messaging, including in community languages, on the one hand, and poor command of English and overall knowledge of Australian systems and society on the other.

The two go hand in hand. A functional knowledge of English is critical to understanding how Australian laws, workplaces, education, and health systems work. Being able to communicate effectively in English makes it easier to seek help and advice and to participate fully in Australian life. While governments can help new migrants with initial settlement and support, new Australians also need to share the responsibility for pro-active learning about their new country.

In his address to the National Press Club in late August, Alan Tudge, Acting Minister for Immigration, Citizenship, Migrant Services and Multicultural Affairs, acknowledged that the COVID-19 pandemic, recession, foreign interference and technology are testing our social cohesion, and announced a range of measures to bolster it. Chief among them is the improvement of the national Adult Migrant English Program (AMEP). The Federal Government should be commended for taking this step.

Equally, a working knowledge of our core community languages is a critical asset for 
those government agencies providing services, our education sector, and the Australian community at large. As our immigration intake accelerated over the past decade, we experienced more urban and cultural fragmentation, especially in Melbourne and Sydney, with emerging suburbs and neighbourhoods hosting one dominant ethnic group, creating geographic and cultural boundaries between these communities and the rest of society.

At the onset of Victoria's second wave, reports emerged of serious errors in translation of critical public health messages in community languages. There was also a lack of outreach to the most vulnerable culturally-diverse communities in the initial hard lock-down stage of the public housing towers.

COVID-19 has also led to an increase in incidents of racism towards Australians of Asian heritage, migrants, students and visitors from Asia. In February 2020, the Australian Human Rights Commission recorded more race-related complaints under the Racial Discrimination Act than in the past year. Since then the rate of complaints has stabilised, but the Commission believes that the data does not tell the full story of the scale of race-related incidents. Other multicultural advocacy groups and the Human Rights Law Centre cite a lack of reporting of racism due to an inadequacy of civil and criminal laws to hold abusers accountable.

These issues are concerning, but they do not yet indicate systemic flaws in our multiculturalism or breakdown in social cohesion. The Scanlon Foundation's authoritative longitudinal "Mapping Social Cohesion" report for 2019 indicates continuing public support for multiculturalism for the period from 2007 to 2019 .

But most of the respondents also believe that nurturing multiculturalism and social cohesion involves mutual responsibility. On the one hand, Australians should do "more to learn about the customs and heritage of different ethnic and cultural groups" present in Australia. On the other, migrant communities need to adopt cultural and social behaviours in line with Australian society and values. The survey, taken before the pandemic, also reports a subtle but nonetheless real long-term 
deterioration in perceptions of safety, discrimination, economic opportunity, acceptance of immigration and a sense of belonging.

Will the annus horribilis of 2020 and the ongoing impact of the pandemic significantly shift these indicators? It is premature to say, but the early signs show that we cannot be complacent.

The risk of a collapse in public and political support for multiculturalism and immigration-gradual or sudden-is likely to grow if the pandemic and the associated economic recession are prolonged in Australia.

The Victorian Government has been swift to recognise the problem, announcing on 13 August 2020 a raft of programs to improve the quality of health messaging in community languages and support for culturally diverse communities. It is a strong and welcome start, especially in the constrained fiscal environment and with so many other pressing priorities.

Will governments Australia-wide have the resources and political capital to continue improving and investing in multicultural policies and programs during the recession? Can they afford not to?

\section{Speaking with our region}

The strength of our multicultural society is a significant asset in our engagement with Asia and the world.

For decades, Australia has been looking for its place in Asia, while building-some argue with varied degrees of success-our Asia literacy and ties with the region. We have a lot to show for it: our economy is plugged into Asia's burgeoning markets and in better, pre-COVID-19, times a rising flow of migrants, students, tourists and investors has contributed to our economy, enriched our society and brought us closer to the region. 
But remarkably, the study of a second language by Australian students has decreased drastically from the 1960s when some $40 \%$ of high school students studied another language, to around 10\% today. In fact, more Australians studied Indonesian in 1972 than they do today. Since well-respected economist Ross Garnaut's call for Asia literacy in 1989 there has been a relative decline in the number of Australians studying Asian languages in schools. A perceived lack of value attached to learning Asian languages has created a self-perpetuating cycle of declining supply of teachers and resources and dwindling demand from students, parents and employers. Moreover, there are structural issues within some of the state school systems creating disincentives to language learning by non-heritage students.

It is not all bad news. Australia is developing its Asia literacy elsewhere. Despite the decline in traditional language studies in schools, the last decade has seen a rise in university and professional programs aimed at improving our understanding of the region.

Before the pandemic, the New Colombo Plan-a signature scholarship program conceived and delivered by then Foreign Minister Julie Bishop-has been sending hundreds of Australian university students to Asia. There are other scholarship schemes specifically targeting Asia, such as Victoria's Hamer scholarships and the Westpac Asian Exchange.

The past decade has also seen the emergence of volunteer-led youth dialogues, building professional and personal networks between the new generations of Australian and Asian leaders.

Australia also has a strong and growing network of independent institutions and university centres that have been instrumental in shaping our Asia engagement. Among them are: Asialink, Asia Institute and Asia Education Foundation, Asia Society Australia, Perth USAsia Centre, China Matters, Australia-Indonesia Centre and Australia-India Institute, ANU Australian Centre for China in the World, 
Australia-China Relations Institute at UTS and other centres with a public and policy interface.

The new National Foundation for Australia-China Relations, a better-resourced and empowered successor to a 40-year old Australia-China Council, will be an influential new player in growing our China competency and facilitating increasingly narrow channels of engagement with the People's Republic of China in a difficult bilateral and global context.

The proliferation of university centres on China is understandable and welcome-the breadth and complexity of the relationship with our largest trading partner requires a diversity of expertise. But often, especially in our universities, investment in China studies occurred in parallel to a steady decline in the studies of other Asian countries critical to our future-Indonesia, India, Japan and Korea. As Australia seeks to diversify its trade partnerships and build diplomatic coalitions in a contested Asia, it needs to invest in our knowledge of Asia beyond China.

For decades, Victoria has been at the forefront of national efforts to build Asia capabilities. The State has an Asia engagement vision and strategy, an advanced and competent public service capacity and an international network to pursue it.

Asialink, Asia Institute, Asia Education Foundation, Asia Society, Australia-Indonesia Centre, and Australia-India Institute are based in Melbourne. The Government's investment in Asia Society's national centre in Melbourne in 2019 is among many other initiatives to support Victoria's ambitious Asia connectivity agenda.

But the COVID-19 pandemic is threatening to reverse these gains, with scholarships and education exchanges on hold, international enrollments stalled, immigration intake dramatically decreased and government and family budgets under stress, threatening the future of Asia engagement institutions and programs.

Yet, as Australia searches for new sources of growth amidst a global recession, and for partners to maintain a rules-based order and a balance of power, it has to find 
them in Asia. It means our businesses, governments and community will need to be well connected with the region and know how its markets, political systems and societies work. With budgetary pressures, it is unrealistic to expect the governments to make major new investments in these capabilities. The key will be to think nationally and laterally to preserve existing institutions and programs that work well, and to build an ecosystem of partnerships between governments, business, education sector and the community to break superficial competition and silos and use our scarce resources wisely.

\section{Solutions}

Australia cannot afford to lose the gains of decades of successful, bi-partisan and whole-of-society efforts to build the world's most successful multicultural society. Neither can it afford to step back from the deepening of our understanding of Asia. Both efforts should be an integral part of our post-COVID economic and social recovery.

As we argued in the inaugural edition of "Disruptive Asia" essay series, our multiculturalism is intricately connected with our global and regional engagement. Most of Australia's new migrants (the UK and New Zealand aside) are from Asia. This is where our top seven trading partners are, and it is a focus of our foreign and national security policy. Understanding our neighbours and engaging newly arrived members of our own community needs to be an integrated national effort.

As in the past, Victoria can lead the nation in building our community and Asia engagement capabilities. Melbourne can be a laboratory for new social and economic policies that will make Australia more inclusive, more resilient and more outward-looking.

Here is where we can start:

First, we must begin by reaffirming Australia's commitment to be an open society 
and economy, welcoming ideas, people and capital from beyond its borders. As we said in our interim report of the Business Council of Australia-Asia Society Taskforce 'A Second Chance'-we must always remind ourselves why Australia needs to be, in Prime Minister Scott Morrison's own words, "an outward-looking, open and sovereign trading economy". Our leaders can extend this description to include a welcoming, culturally competent and inclusive society. It will be a positive message to send to our community drained by COVID-19 and the recession. It will also help to re-position Australia's global trade, investment and talent attraction agenda for the post-pandemic future.

For example, the Federal Government has recently announced the establishment of a Taskforce to attract global business and talent to Australia. The strength and cohesion of our multicultural, multilingual and open society will certainly be attractive to the world's best minds.

Second, English language is fundamental to the success of Australian multiculturalism. Knowing and using it saves lives-especially in pandemics and other emergencies-improves education and economic prospects and builds vital societal ties. Australia already has a highly effective program-the Australian Migrant English Program (AMEP)-which for 71 years has been helping new Australians to learn English and settle into Australian life. But as our immigration patterns change, AMEP too must evolve. The review of the program by the Scanlon Foundation recommends seven practical and achievable steps to expand and renew the program. The announcement by the Acting Minister for Immigration, Citizenship, Migrant Services and Multicultural Affairs Alan Tudge to overhaul and expand the AMEP suggests that the Government is moving to implement these vital changes. AMEP should be supplemented by state initiatives, working in tandem with each other, but customised to different local circumstances.

For example, Victoria and New South Wales could consider designing specialised English language and settlement support programs for their dominant migrant groups from China and India, or for the least advantaged and vulnerable groups. Our 
tertiary and vocational education sector-highly versed in delivering English language programs for fee-paying international students onshore and offshore-can offer its expertise and capacity to improve English competency needs of our community. These measures should be linked to continuing funding and empowerment of well-performing institutions and programs, such as the Victorian Multicultural Commission and Multicultural NSW, and successful inclusion programs by Royal Life Saving Australia and Melbourne Football Club.

Third, we need to preserve the institutions and programs (and their core operational funding) that build our Asia competency. As a group of eminent Asia engagement professionals will argue in the upcoming policy paper under the Business Council of Australia-Asia Society Taskforce-we need to spotlight the successes and secure and scale-up institutions and programs which have proven to deliver results.

The pandemic is also an opportunity to re-imagine and reinvent our national approach to Asia literacy, and broaden its definition. Too often, Asia literacy in Australia has been defined in narrow academic terms of linguistic and cultural competency. The policy of mass Asia literacy programs at scale with a focus on schools has not delivered the results we expected. It does not mean we should completely give up on it. But we should at least learn from our failures and start afresh.

There is a place for deep, academically rigorous, multi-year or lifetime study of Asian languages at school and university level with complete fluency as the ultimate outcome. But we also need to enable Australians to learn about Asia and engage with the region at different points of their life, while pursuing other studies and professional endeavours. Such an approach will create an Asia competency ecosystem which will connect different tiers of our education system, employers and community and unlock the power of digital technologies. It will offer a wide range of education, lifelong-learning and professional development opportunities to Australians to stay informed about Asia. 
It is here that our universities can play a leadership role. For example, in partnerships with industry bodies and non-profits, they can offer Asia-focused microcredentials to undergraduates, executive programs to State government officers and exporters and embed Asia economic literacy in their postgraduate business programs. The New Colombo Plan and other scholarship schemes should work with universities, employers and Asia literacy bodies to maintain their alumni's interest in Asia and advocate for the importance of Asia competencies skills among Australian employers, graduates, parents and schools.

Finally, the solutions to the challenges above also lie within our own community.

As a start, practical and essential government communications to culturally and linguistically diverse communities can improve through inviting these communities to craft them. Monash University research recommends five practical steps to improve this vital messaging, especially in emergencies.

But we can go further. By enabling greater participation of Asian-Australians (and Australians of other non-European migrant groups) in the leadership of our institutions, we will build a more inclusive and culturally competent leadership pool, representative of our society. The 2018 'Leading for Change' report found on average only 3\% of Australian senior business, political, public service and university leaders are from non-Anglo-Celtic and European backgrounds. Cultural diversity improves only slightly at the senior management level, with $95 \%$ of more than 2,400 senior leaders having an Anglo-Celtic or European background. It challenges Australia's egalitarian self-image and undermines our prosperity which relies upon international trade, capital inflows and mobility of people, mainly from our region.

A diverse leadership will embed a vital cultural intelligence in our public service, politics, media, business, and education institutions, so they can speak with our community and our region confidently and effectively. We are already doing it. But we can all do better at making our leadership and teams, our panels and publications reflect the fabric of our community. Just like we are shifting the dial in gender 
equality, we can make progress in enabling a true cultural diversity in our leadership. We have Gladys Liu and Penny Wong in our Parliament. We have Ambassador James Choi representing our nation in the Republic of Korea, and Harinder Sidhu has just finished her term as our High Commissioner to India. Shemara Wikramanayake is the CEO of Macquarie Bank, one of Australia's most successful global companies. And we are a better country for them, not only because of their talents and intellect, but because they serve as role models to those that come behind them.

Australia is at a critical juncture. The pandemic exposed our economic, political and social vulnerabilities. But it also showed resilience and the strength of our national character. Our multiculturalism and our knowledge about Asia are intrinsic features of this character. Both are holding up against the adversity of this once-in-ageneration crisis. But cracks and weaknesses are appearing. It is within our reach to ensure they do not become the fault lines that divide us.

This article is an edited version of the Asia Society Australia policy paper for the Victorian Government.

Image: Chinese Lunar New Year in Melbourne. Credit: Chris PhutullyFlickr 